\title{
SPONTANEOUS BACTERIAL PERITONITIS;
} Frequency of asymptomatic in patients of liver cirrhosis.

1. Senior Registrar Medical Unit-1

Ghurki Trust Teaching Hospital, Lahore

Correspondence Address: Dr. Ahsan Ayub

Lasani House Manawan,

Batapur, Lahore

drwillana@hotmail.com

Article received on:

31/03/2014

Accepted for Publication:

05/07/2014

Received after proof reading:

$16 / 08 / 2014$

\section{INTRODUCTION}

Cirrhosis of liver is a chronic process characterized by structurally abnormal nodules in the liver with diffuse, generalized increase in fibrous tissue throughout liver ${ }^{1,2}$. In all patients of cirrhosis of liver the triad parenchymal necrosis, regeneration, and scarring is present ${ }^{3}$. The over all incidence is 360 per 100,000 . In western countries alcohol is the most common cause of cirrhosis of liver, but in our country hepatic viruses particularly $\mathrm{B}$ and $\mathrm{C}$ are the most common causes ${ }^{4}$.

Cirrhosis apart from other features peculiar to the cause results in two major events; hepatocellular failure and portal hypertension. The former is assessed by the presence of jaundice, ascites, encephalopathy, low serum albumin, raised aminotransferases (ALT, AST) level and prothrombin (PT) deficiency not corrected by vitamin K. Portal hypertension is demonstrated by splenomgaly, oesophageal varices, and ascites and by measuring portal pressure ${ }^{4}$.
Ascites is defined as the collection of free fluid in the peritoneal cavity. More than $500 \mathrm{ml}$ of fluid must be present before ascites can be presented clinically ${ }^{5}$.

Spontaneous Bacterial Peritonitis(SBP) is defined as the infection of ascitic fluid without any apparent intra abdominal focus of infection in patients of cirrhosis of liver ${ }^{6,7}$. Spontaneous bacterial peritonitis is a common complication in patients of cirrhosis of liver.

The signs and symptoms of SBP are subtle compared with those of patients who have surgical peritonitis in the absence of ascites. Ascites prevent the development of rigid abdomen by separating the visceral pleura from the parietal pleura. The most common clinical features of spontaneous bacterial peritonitis are abdominal pain, abdominal tenderness, abdominal discomfort and fever.

Patients of cirrhosis of liver with spontaneous 
bacterial peritonitis may be asymptomatic not having the clinical sign and symptoms of peritonitis like abdominal pain, abdominal discomfort, and fever. Patients with asymptomatic SBP have less severe disease than symptomatic SBP. They usually have lower mortality rate than symptomatic SBP. As spontaneous bacterial peritonitis can be silent so in order to make the diagnosis of SBP abdominal paracentesis is necessary.

Despite the effective treatment of SBP it has the high morbidity and mortality. Mortality rate of SBP is $70 \%$ per one year due to the complications like septic shock, hepatorenal syndrome, and hepatic encephalopathy ${ }^{9}$.

Various international studies show that 10 to $30 \%$ of patients of cirrhosis of liver develop SBP, and $10 \%$ of these patients are asymptomatic not having the signs and symptoms of $\mathrm{SBP}^{10}$.

Since SBP has high mortality and the morbidity it necessitates the need of early diagnosis of SBP ${ }^{11}$

\section{OBJECTIVE}

1. To assess the frequency of asymptomatic SBP in patients of cirrhosis of liver in order to reduce the mortality from liver cirrhosis.

2. To assess the possibility of developing criteria for the diagnosis of asymptomatic SBP in patients of cirrhosis of liver.

\section{OPERATIONAL DEFINITIONS \\ Cirrhosis of liver}

Cirrhosis of liver is defined as the fibrosis and nodular regeneration of liver leading to hepatocellular failure and portal hypertension.

\section{Asymptomatic spontaneous bacterial peritonitis. \\ It is defined as the infection of ascitic fluid with out the clinical features of peritonitis like: abdominal pain, abdominal tenderness, fever and having the following criteria: \\ 1. Polymorph nuclear cell count more than 250 cells per cubic millimeter. \\ 2. Serum-Ascitic Albumin Gradient (SAAG)}

more than $1.1 \mathrm{gm}$ per deciliter.

3. Positive monomicrobial culture.

Serum-ascitic albumin gradient (SAAG)

It is defined as the difference between the serum albumin minus ascitic albumin.

- If it is more than $1.1 \mathrm{gm}$ per deciliter it is defined as transudative ascitic fluid. It is due to portal hypertension.

- If it is less than $1.1 \mathrm{gm}$ per deciliter it is defined as exudative and is due to tuberculosis or malignancy.

\section{MATERIAL AND METHODS}

It was descriptive cross sectional study conducted in hepatitis clinic of medical unit 1 Services hospital, Lahore for aperiod of one year. Total 100 patients were included in the study. Non probability sampling technique was used. Cirrhotic patients of both sexes, of all ages and of any etiology were included in the study.

Cirrhotic patients with ascites having abdominal pain, abdominal tenderness and fever, malignant ascites, tuberculous ascites, history of antibiotic use with in seven days prior to hospital admission and patients with evidence of intra abdominal infection were excluded from the study.

All patients who were included in the study were undergone detailed history and detailed physical examination. All basic investigations were carried out to rule out other diseases. All patients of cirrhosis of liver were undergone diagnostic ascitic paracentesis. Total $30 \mathrm{ml}$ of ascitic fluid was aspirated and was divided into three parts. One part was inoculated into blood culture bottle and was sent for culture growth and other two portions were sent for cytology and biochemistry. All the obtained data was entered in specially designed proforma. The diagnosis of spontaneous bacterial peritonitis was made on the basis of the following criteria;

\section{A-Culture positive SBP}

- $\quad$ The positive ascitic fluid culture.

- Polymorphonuclear cells count in ascitic fluid more than 250 cells per cubic $\mathrm{mm}$. 
- Serum Ascitic Albumin Gradient more than $1.1 \mathrm{gm}$ per dl.

\section{B-Culture negative SBP}

- $\quad$ Negative ascitic fluid culture.

- $\quad$ Polymorphonuclear cells count more than 250 cells per cubic $\mathrm{mm}$.

- $\quad$ Serum-ascitic albumin gradient (SAAG) more than $1.1 \mathrm{gm}$ per dl.

\section{C-Bacterascites (BA)}

- $\quad$ Positive ascitic fluid culture.

- $\quad$ Ascitic fluid polymorphonuclear cell count less than 250 cells per cubic $\mathrm{mm}$.

All collected data was entered on computer, using the SSPS soft ware

\section{RESULTS}

Ten patients $(10 \%, 95 \% \mathrm{Cl} 4 . \mathrm{I}$ to 15.9$)$ were SBP positive and ninety patients $(90 \%, 95 \% \mathrm{Cl} 84.1$ to 95.9) were SBP negative. Table-I, Fig-1.

Six patients $(60 \%)$ with SBP positive $(n-10)$ were up to 50 years of age and four patients (40\%) with SBP positive ( $\mathrm{n}-10)$ were less than 50 years. Forty four patients (48.9\%) with out SBP (n-90) were upto 50 year, and 46 patients $(51.1 \%)$ with out SBP $(n-90)$ were below 50 year. $(P$-value $=0.51)$. Table-II

Four patients (40\%) with SBP positive (n-10) were male and six patients (60\%) with SBP positive were females. 65 patients with out SBP $(n-90)$ were males and 25 patients (27.8) were females. (Chi$\mathrm{Sq}=4.369, \mathrm{p}$-value $=0.04$ ) Table-II

Moderate ascites was present in $30 \%$ of patients (3 patients) with SBP positive (n-10) and tense ascites was present in $70 \%$ of patients (7) with SBP positive (n-10) (Fisher's exact test p-
Parameters
Freq.
\%age
95\% Confidence Interval

Spontaneous bacterial peritonitis

\begin{tabular}{|l|r|}
\hline Present & 10 \\
\hline Absent & 90 \\
\hline
\end{tabular}

\begin{tabular}{l|l}
\hline 10 & $10 \%$ \\
\hline
\end{tabular}

\begin{tabular}{l|l}
$10 \%$ & 4 \\
\hline
\end{tabular}

\begin{tabular}{r|r}
\hline 4.1 & 15.9 \\
\hline
\end{tabular}

\begin{tabular}{l|l}
90 & $90 \%$
\end{tabular}

84.1

95.9

Ascitic fluid culture

Negative 98

$98.0 \%$

95.3

100.7

Positive

2

$2.0 \%$

$-0.7$

4.7

Table-I. Distribution of patients according to Ascitic fluid culture and Spontaneous Bacterial Peritonitis

\begin{tabular}{|c|c|c|c|c|c|}
\hline \multirow{3}{*}{$\begin{array}{c}\text { Patient } \\
\text { Characteristics }\end{array}$} & \multicolumn{4}{|c|}{ Spontaneous bacterial peritonitis } & \multirow{3}{*}{$\begin{array}{c}\text { Significance } \\
\text { Test }\end{array}$} \\
\hline & \multicolumn{2}{|c|}{ Present $(n=10)$} & \multicolumn{2}{|c|}{ Absent $(n=90)$} & \\
\hline & No. & $\%$ & No. & $\%$ & \\
\hline \multicolumn{6}{|l|}{ Patient Age } \\
\hline Up to 50 years & 6 & $60.0 \%$ & 44 & $48.9 \%$ & \multirow{2}{*}{$\begin{array}{l}\text { Chi-Sq }=0.444 \\
P \text {-value }=0.51\end{array}$} \\
\hline$>50$ years & 4 & $40.0 \%$ & 46 & $51.1 \%$ & \\
\hline \multicolumn{6}{|l|}{ Patient Sex } \\
\hline Males & 4 & $60.0 \%$ & 65 & $72.2 \%$ & \multirow{2}{*}{$\begin{array}{l}\text { Chi-Sq }=4.369 \\
P \text {-value }=0.04\end{array}$} \\
\hline Females & 6 & $40.0 \%$ & 25 & $27.8 \%$ & \\
\hline
\end{tabular}




\begin{tabular}{|c|c|c|c|c|c|}
\hline \multirow[t]{3}{*}{ Parameters } & \multicolumn{4}{|c|}{ Spontaneous bacterial peritonitis } & \multirow{3}{*}{ Significance Test } \\
\hline & \multicolumn{2}{|c|}{ Present $(n=10)$} & \multicolumn{2}{|c|}{ Absent $(n=90)$} & \\
\hline & No. & $\%$ & No. & $\%$ & \\
\hline \multicolumn{6}{|l|}{ Types of Ascites } \\
\hline Moderate Ascites & 3 & $30.0 \%$ & 86 & $95.6 \%$ & \multirow{2}{*}{$\begin{array}{c}\text { Fisher's exact test } \\
\text { p-value }<0.01\end{array}$} \\
\hline Tense & 7 & $70.0 \%$ & 4 & $4.4 \%$ & \\
\hline \multicolumn{6}{|c|}{ Hepatic Encephalopathy } \\
\hline No encephalopathy & 6 & $60.0 \%$ & 90 & $100.0 \%$ & \multirow{2}{*}{$\begin{array}{c}\text { Fisher's exact test } \\
\text { p-value }<0.01\end{array}$} \\
\hline Mild & 4 & $40.0 \%$ & - & $.0 \%$ & \\
\hline \multicolumn{6}{|l|}{ Child's Grade } \\
\hline Grade B & - & $-0 \%$ & 60 & $66.7 \%$ & \multirow{2}{*}{$\begin{array}{c}\text { Fisher's exact test } \\
\text { p-value }<0.01\end{array}$} \\
\hline Grade C & 10 & $100.0 \%$ & 30 & $33.3 \%$ & \\
\hline
\end{tabular}

value $<0.01)$. Table-III

Moderate ascites was present in $95.6 \%$ of patients (86patients) with out SBP and tense ascites was present in $4.4 \%$ of patients with out SBP (n90). Table-III

$60 \%$ of patients (6patients) with SBP positive (n10 ) had no encephalopathy and $40 \%$ of patients (4 patients) with SBP had mild encephalopathy. (Fisher's exact test p-value $<0.01$ ). $100 \%$ of patients (90 patients) without SBP had no encephalopathy.Table-III

All patients with SBP positive were in child Pugh class C (n-10).Sixty patients (66.7\%) with out SBP were in child Pugh class $B$ and thirty patients (33.3\%) with out SBP were in child Pugh class $C$ ( $n$ 90), Fisher's exact test p-value <0.01). Table-III

All patients (100\%) with SBP positive had sever deficiency of serum albumin (n-10) while ten patients $(11.1 \%)$ with out SBP had normal serum albumin, fifty one patient (56.7\%) with out SBP had mild deficiency of serum albumin and 29 patients $(32.2 \%)$ with SBP had sever deficiency of serum albumin (n-90). (Chi-square $=17.379$, DF $=2, p$ value $=<0.01)$. Table-IV
All patients (100\%) with SBP positive had severely raised serum billirubin( $n-10)$, While twenty one patients $(23.3 \%)$ with out SBP had mildly raised serum bilirubin, forty one patient $(45.6 \%)$ with out SBP had moderately raised serum bilirubin and twenty eight patients (31.1\%) without SBP had severely raised bilirubin $(\mathrm{n}-90)$. (Chi -square $=$ 18.129, DF $=2$, p-value $<0.01$ ). Table-IV

All patients (100\%) with SBP positive had severely prolonged prothrombin time $(n-10)$, while nine patients (10\%) with out SBP had normal prothrombin time. Forty seven patients (52.2\%) with out SBP had moderately prolonged prothrombin time and thirty four patients (37.8\%) with out SBP had severely prolonged prothrombin time $(n-90)$. (Chi square $=14.141$, DF $=2, p$-value $<0.01)$. Table-V

Three patients (30\%) with SBP positive had no pus cells in urine and seven patients $(70 \%)$ with SBP had pus cells in the urine $(n-10)$. while ninety patients (100\%) with out SBP had no pus cells in urine $(n-90)$. (Fisher's exact test $p$-value $<0.01)$.Table-V 
Parameters

Spontaneous bacterial peritonitis

$$
\text { Present }(n=10)
$$

Absent $(n=90)$

No.

$\%$

\begin{tabular}{c|c|c|}
\hline- & $.0 \%$ & 10 \\
\hline- & $.0 \%$ & 51 \\
\hline 10 & $100.0 \%$ & 29 \\
\hline
\end{tabular}

\begin{tabular}{|l|l|}
\hline 10 & $11.1 \%$ \\
\hline 51 & $56.7 \%$ \\
\hline 29 & $32.2 \%$ \\
\hline
\end{tabular}

Chi-Sq $=17.379$

df $=2$

P-value $<0.01$

Severe deficiency

Serum Bilirubin**

Mildly raised

Moderately raised

Severely raised

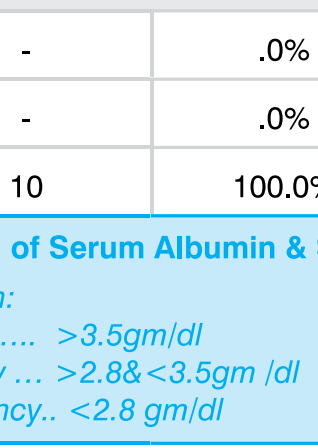

Spontaneous bacterial peritonitis

Parameters

Serum Albumin:

Normal............ > $>3.5 \mathrm{gm} / \mathrm{d}$

Mild deficiency ... $>2.8 \&<3.5 \mathrm{~g}$
Severe deficiency.. $<2.8 \mathrm{gm} / \mathrm{d}$

$(n=10)$

Absent $(n=90)$

$23.3 \%$

Chi-Sq $=18.129$

$\mathrm{df}=2$

$45.6 \%$

$P$-value $<0.01$

Test

Table-IV. Comparison of Serum Albumin \& Serum Bilirubin with Spontaneous Bacterial Peritonitis

Serum Bilirubin:

Mildly raised....... $<2 m g / d l$

Moderately raised.. 2-3mg/dl

Moderately raised. $>3 \mathrm{mg} / \mathrm{dl}$

\begin{tabular}{|c|c|c|c|c|c|}
\hline \multirow[t]{3}{*}{ Parameters } & \multicolumn{4}{|c|}{ Spontaneous bacterial peritonitis } & \multirow{3}{*}{ Significance Test } \\
\hline & \multicolumn{2}{|c|}{ Present $(n=10)$} & \multicolumn{2}{|c|}{ Absent $(n=90)$} & \\
\hline & No. & $\%$ & No. & $\%$ & \\
\hline \multicolumn{6}{|c|}{ Prothrombin time (Seconds)* } \\
\hline Normal & - & $.0 \%$ & 9 & $10.0 \%$ & \multirow{3}{*}{$\begin{array}{l}\text { Chi-Sq }=14.141 \\
\text { df }=2 \\
\text { P-value }<0.01\end{array}$} \\
\hline Moderately prolonged & - & $.0 \%$ & 47 & $52.2 \%$ & \\
\hline Severely prolonged & 10 & $100.0 \%$ & 34 & $37.8 \%$ & \\
\hline \multicolumn{6}{|l|}{ Urine pus cell } \\
\hline No pus cells & 3 & $30.0 \%$ & $100.0 \%$ & $100.0 \%$ & \multirow{2}{*}{$\begin{array}{l}\text { Fisher's exact test } \\
\text { P-value }<0.01\end{array}$} \\
\hline Pus cell present & 7 & $70.0 \%$ & $.0 \%$ & $.0 \%$ & \\
\hline \multicolumn{6}{|c|}{ Table-V. Comparison of prothrombin time \&Urine Pus Cells with Spontaneous bacterial Peritonitis } \\
\hline \multicolumn{6}{|c|}{$\begin{array}{lr}\text { Prothrombin time (PT): } & \\
\text { Normal } & \text { Within 3 sec. } \\
\text { Moderately prolonged } & 4-6 \\
\text { Severely prolonged } & >6\end{array}$} \\
\hline
\end{tabular}

\section{DISCUSSION}

The aim and objective of this study was to determine the frequency of SBP in asymptomatic patients of cirrhosis with acsites.
The majority of patients were in the 35 to 55 years of age group. This is comparable with the previous study ${ }^{11}$. As cirrhosis of liver is a chronic process the majority of the patients develop various complications in this age range. 


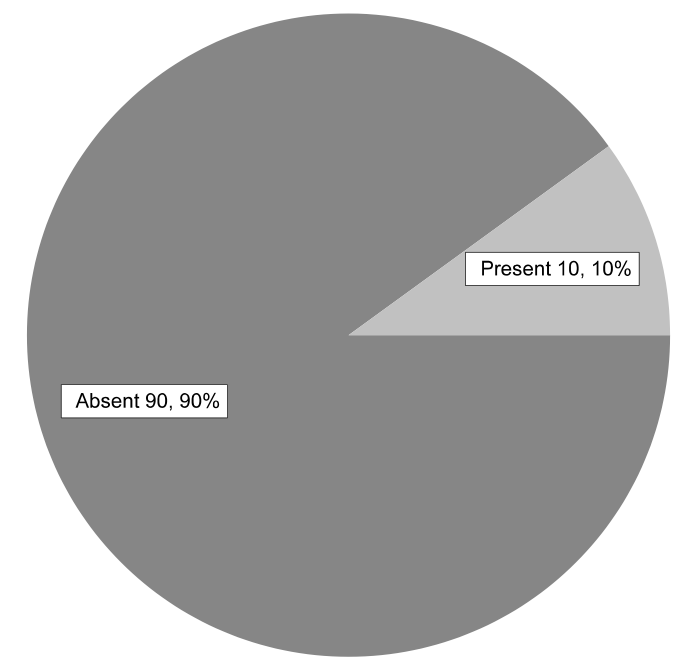

Figure-1. Distribution of patients according to Spontaneous Bacterial Peritonitis

Hepatitis B and C were commonest causes of cirrhosis in our patients. Alcoholic cirrhosis is rare in our set up because of the lesser alcohol intake by the general population due to religious restriction. Higher frequency of viral etiology is probably due to unawareness in general population regarding the spread of viruses. Use of non-disposable syringes is still prevalent in our country. Blood is not checked for viral markers in all centers before blood transfusion. Other factors contributing to the wide spread of $\mathrm{B}$ and $\mathrm{C}$ viruses in our set up are nasal and ear pricking by unsterlized instruments and wide spread quack practice. Our population thus has higher chances of acquiring these infections due to these factors.

Most of patients in this study who have asymptomatic SBP had abnormal liver function tests. The common abnormalities were raised billirubin level, decreased albumin level and prolong prothrombin time. This is due to the advanced liver disease at the time of presentation.

In lab investigation of our SBP patients we incidentally found that out of total 10 SBP positive patients 6 were having significant pus cells in the urine and these patients were not having the classical symptoms of urinary tract infection. This evidence is consistent with study by $\mathrm{HOH}$ et al who found that asymptomatic bacteriuria occurs often in association with community acquired spontaneous bacterial peritonitis ${ }^{12}$.

In various international studies it has been shown that 10 to $30 \%$ patients of cirrhosis of liver develops SBP ${ }^{13-14}$. Similar studies are also carried in the various centers of Pakistan. Studies conducted at Agha Khan University Hospital, ${ }^{15}$ Jinnah Post Graduate Medical center, ${ }^{16}$ and Lahore ${ }^{17}$ it was $33 \%, 17 \%$ and $33 \%$ respectively.

In present study our interest was to find out the frequency of SBP in asymptomatic patients of cirrhosis of liver. In our study we have found that $10 \%$ of asymptomatic patients of cirrhosis of liver were having SBP. Our study is in consistent with the study of Khan M D et al who found that $9.3 \%$ of patients of cirrhosis of liver were having asymptomatic SBP at their first clinical presentation $^{18}$.

Our study is also inconsistent with study of Azam et al who found that $10 \%$ of patients were absolutely asymptomatic, but they were having SBP.

Romney $\mathrm{R}$ et al conducted a study whose results were absolutely contradicted to our results. In his study he could not find any case of asymptomatic SBP among cirrhotic out patients. He concluded that there is no need to carry out exploratory paracentesis in asymptomatic patients of cirrhosis of liver ${ }^{19}$. I was surprised that this study was against the guide lines of American association for the study of liver diseases who recommended performing exploratory paracentesis on each patient with cirrhosis of liver and having ascites.

Present study suggested that $10 \%$ asymptomatic patients of cirrhosis with ascites were having SBP. This study also points out that patients of SBP were having abnormal liver function tests and asymptomatic pyurea.

\section{CONCLUSIONS}

We concluded that $10 \%$ of asymptomatic patients of cirrhosis with ascites are having SBP, so it is a common complication in our set up so patients 
with cirrhosis of liver with ascites having disturbed liver function tests (prolong pt, raised bilirubin, low serum albumin) and asymptomatic pyurea should be strongly evaluated for SBP and actively treated in order to reduce the morbidity and mortality of the disease. However further studies are required to find out the sensitivity and specificity of asymptomatic pyurea in SBP patients.

\section{Copyright@ 05 July, 2014.}

\section{REFERENCES}

1. Sherlock S, Dooly J. Hepatic cirrhosis and portal venous system and portal hypertension. In: Sherlock S, Dooley J, editors. Diseases of liver and biliary tract. 10thed. London: Blackwell Science, 1997: 706-27.

2. Con HO, Atterbury CE. Cirrhosis. In: Schiff ER, editor. Diseases of liver. 7thed. Philadelphia: J.B. Lippincot, 1993:875-95.

3. Finlayson ND, Boucher LD, Haslett C, Chilvers ER. Liver and biliary tract disease. In: Davidson's Principles and practice of Medicine. 19thed. London: Chirchill Livingstone, 2002:483-546.

4. Kumar P, Clark M. Liver, billiary tract and pancreatic disease. In: Clinical medicine, a textbook for medical students and doctors. 6thed. London: W.B. Saunders, 2005:347-417.

5. Burroughs AK. Management of chronic liver disease. Med Int 1994; 7:485-94.

6. Amin K, Alam MM, Abbas G, Mehmood K, Irshsdul-Haq. Spontaneous bacterial peritonitis; prevalence in cirrhotic patients. Prof Med $\mathrm{J}$ 2000; 7:346-51.

7. Such J, Runyon BA. Spontaneous bacterial peritonitis. C Llin Infec Dis 1998; 27:659-77.

8. Azam M, Haider N, Masood J. Prevalence of asymptomatic spontaneous bacterial peritonitis in cirrhotic patients. Pak Postgrad Med J 1999; 10:38-39.
9. Khan $\mathrm{MH}$. Spontaneous bacterial peritonitis. J Coll Physicians Surg Pak 1999; 9:345-6.

10. Jaffary W, Shah $H$, Hameed S. Spontaneous bacterial peritonitis. Specialist 1992; 8:33-8.

11. Shaikh S. Portal-systemic encephalopathy in cirrhotic liver disease: Experience at Peoples Medical College, Nawabshah. J Coll Phys Surg Pak 1998; 8: 53-5.

12. Ho H, Zuckerman MJ, Ho TK, et al. Prevalence and associated infections in community acquired spontaneous bacterial peritonitis. Am J Gastroenterol 1996; 91:735-42.

13. Kaymakoglu S, Eraksoy H, Okten A, Demir K, Calangu S, Cakalogu Y, et al. Spontaneous ascitic infections in different cirrhotic groups: prevalence risk factors and the efficacy of cefotaxime therapy. Eur J Gastroenterol hepatol 1997; 9:71-6.

14. Khan $\mathrm{MH}$. Spontaneous bacterial peritonitis. JCPSP 1999; 9:345-6.

15. Jaffary W, Shah $H$, Hamid S. Spontaneous bacterial peritonitis. Specialists 1992; 8:33-8.

16. Baqai R, Zuberi SJ, Hassan R. Frequency of ascitic fluid infection in cirrhotics. $J$ Pak Med Res 1993; 32:76-8.

17. Chaudhry ZI, Khokar MS. Spontaneous bacterial peritonitis. Specialist 1993; 3:277-89.

18. Khan DM, Sh RA, Ashfaq M, et al. Frequency of asymptomatic spontaneous bacterial peritonitis in chronic liver disease patients with first presentation of ascites. Ann King Edward Med Coll Jun 2004; 10:144-5.

19. Romney R, Mathurin P, Ganne-Carrie N, Halimi C, Medeni A, Lemaitre $P$, et al. Usefulness of routine analysis of ascitic fluid at the time of therapeutic paracentesis in asymptomatic out patients. Gastrenterol Clin Biol 2005; 29:275-9. 